\title{
CrimRxiv
}

\section{How Humans Judge Machines}

César A. Hidalgo, Diana Orghian, Jordi Albo Canals, Filipa de Almeida, Natalia Martin

Published on: Feb 01, 2021

DOI: $10.21428 / c b 6 a b 371 . a 6 b c 9 c b 4$

License: Creative Commons Attribution 4.0 International License (CC-BY 4.0). 
